\title{
What is the Effect of Accompanying Ankylosing Spondylitis in Treatment of Multiple Sclerosis? Is there a Resistance?
}

\author{
Multipl Sklerozda Eşlik Eden Ankilozan Spondilitin Tedaviye Etkisi ne Düzeydedir? Bir \\ Direnç Söz Konusu Olabilir mi?
}

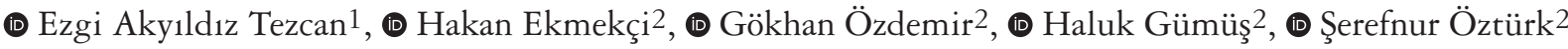

1Selcuk University Faculty of Medicine, Department of Physical Medicine and Rehabilitation, Konya, Turkey

2Selcuk University Faculty of Medicine, Department of Neurology, Konya, Turkey

Keywords: Ankylosing spondylitis, multiple sclerosis, demyelination

Anahtar Kelimeler: Ankilozan spondilit, multipl skleroz, demyelinizasyon

\section{Dear Editor,}

Multiple sclerosis (MS) is an autoimmune central nervous system disease characterized by inflammation, demyelination, and axonal damage (1). Ankylosing spondylitis (AS) is a common inflammatory rheumatic disease affecting the axial skeleton, which can cause structural and functional disorders and decreased quality of life, and cause a characteristic back pain and position (2). The coexistence of MS and AS is rare. Besides the neurogenetic and neuroepidemiologic aspects of this association, there may be an interactive interaction in the treatment. It may be necessary to examine the effect of this situation on the roadmap to be followed in the treatment of both diseases.

A 36-year-old female patient with MS was admitted to our clinic. She had been followed due to MS for five years, but she stated that the disease was steadily progressing with attacks. She reported that the difficulty of walking was followed by the loss of strength affecting the extremities. T2-weighted magnetic resonance imaging (MRI) revealed a large number of plaque-like lesions perpendicular the ventricular system in the periventricular white matter of both cerebral hemispheres and also showed plaques and increases in signal in cervical and thoracic regions (Figure 1). In the family history of the patient, the daughter of her uncle was also followed due to MS. Oligoclonal band type II was detected in the study of cerebrospinal fluid of our patient. Although the patient had previously used glatiramer acetate, azathioprine, fampridine, fingolimod, and rituximab, the disease could not be controlled. There was no significant finding in the multi-modal evoked potentials except for the prolongation of latency in visual pathways. It was learnt that she had been followed up since 2012 because of AS and that the diagnosis of MS was made one year later. Contrast-enhancing sacroiliac MRI performed at the external center due to admission of the patient with inflammatory lower back pain revealed bilateral asymmetric sacroiliitis. HLAB27 and HLAB52 were found to be positive in the patient's genetic test.

The patient still uses indomethacin and sulfasalazine due to AS. An eye examination of the patient in 2017 showed temporal atrophy in the left eye, prolongation of bilateral visual evoked potential latencies, and significant retinal nerve fiber loss in the optical coherence tomography. In the last examination, the patient was only able to take a few steps unaided; she was paraparetic (prominent in the lower right extremity) and she had severe spasticity in the lower extremities. The expanded disability status scale score was 5.5. Treatment with ocrelizumab was planned for our patient who has been followed up due to primary progressive MS.

The association of AS and MS has been shown in a limited number of cases in the literature. Wendling et al. (3) reported the largest series in the literature. Twenty-one cases were reported in this series and it was reported that one disease had no effect on the treatment of the other over a 5.2-year follow-up period. Lourbopoulos et al. (4) suggested in a case series that if a patient did not meet the diagnostic criteria of MS, the treatment of MS

Address for Correspondence/Yazışma Adresi: Ezgi Akyıldız Tezcan MD, Selcuk University Faculty of Medicine, Department of Physical Medicine and Rehabilitation, Konya, Turkey

Phone: +905075815158 E-mail: drezgiakyildiz@gmail.com ORCID: orcid.org/0000-0002-4988-1270

Received/Geliş Tarihi: 19.12.2018 Accepted/Kabul Tarihi: 09.03.2019

${ }^{\oplus}$ Copyright 2019 by Turkish Neurological Society

Turkish Journal of Neurology published by Galenos Publishing House. 

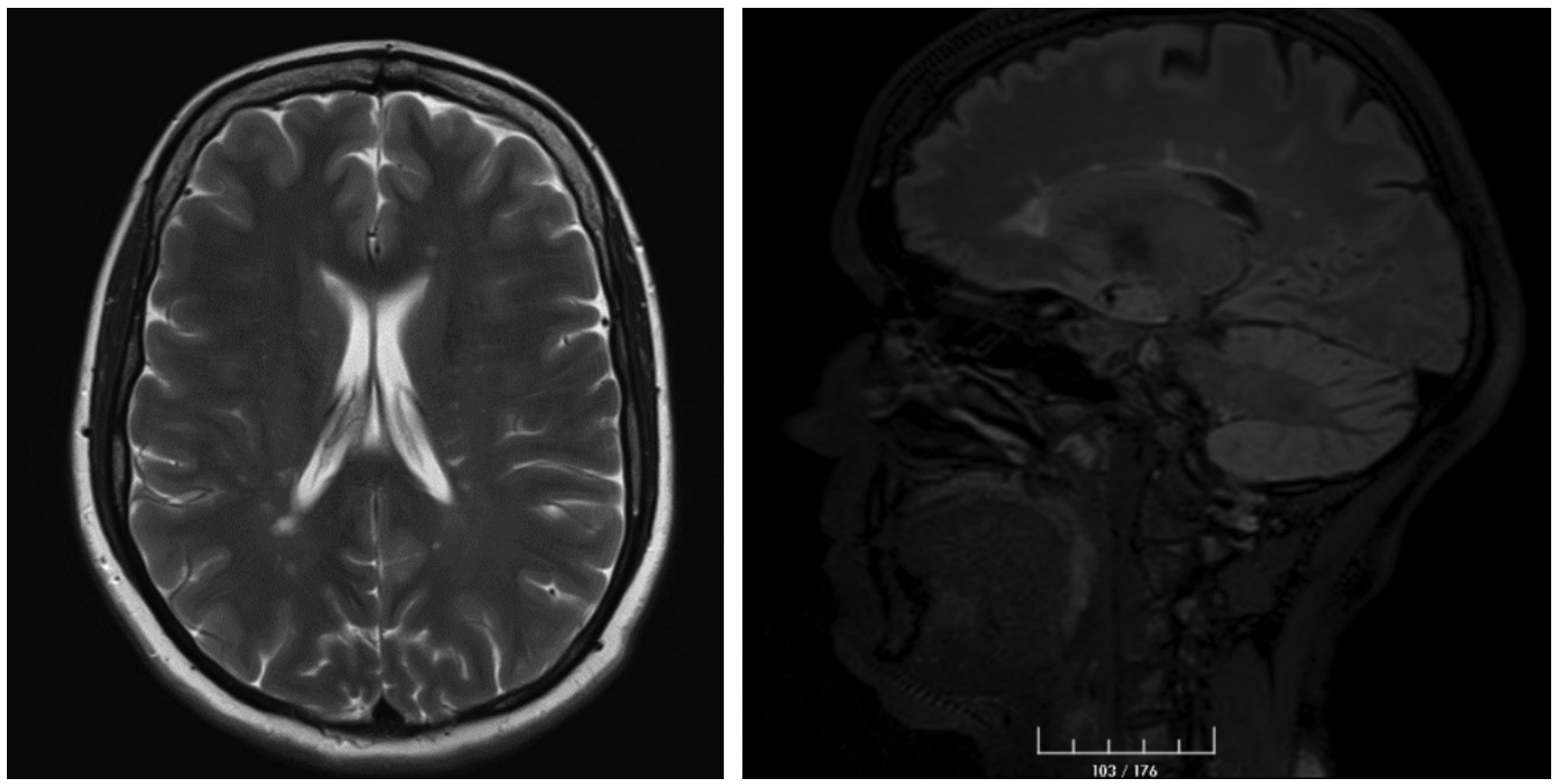

Figure 1. Large number of plaque-like lesions perpendicular to the ventricular system in the periventricular white matter of both cerebral hemispheres

should be ceased and that performing MRI once every 6-12 months and clinical follow-up would be sufficient. In the case of definitive MS, the authors recommended the use of interferon-beta or glatiramer acetate in the first step. In another study by Omair et al. (5) rituximab was suggested as an alternative in the presence of AS and demyelinating disease, but the demyelinating disease in this case developed secondary to treatment against tumor necrosis factor-alpha. There is no data on the efficacy of sulfasalazine in MS. The treatment of AS and MS, as well as the effect of diseases on progression are not fully known. As in our case, more research on AS comorbidity in patients with primary progressive MS is needed.

\section{Ethics}

Informed Consent: Consent form was taken.

Peer-review: Internally peer-reviewed.

\section{Authorship Contributions}

Surgical and Medical Practices: G.Ö., H.G., Concept: H.E., Design: E.A.T., H.E., Data Collection or Processing: E.A.T., H.E.,
G.Ö., H.G., Analysis or Interpretation: H.E., Ş.Ö., Literature Search: E.A.T., H.E., Writing: E.A.T., H.E.

Conflict of Interest: No conflict of interest was declared by the authors.

Financial Disclosure: The authors declared that this study received no financial support.

\section{References}

1. Türk Nöroloji Derneği, Multipl Skleroz tanı ve tedavi kılavuzu, 2016.

2. Braun J, Sieper J. Ankylosing spondylitis. Lancet 2007;369:1379-1390.

3. Wendling D, Flipo RM, Breban M, et al. Coexistence of spondyloarthropathy and multiple sclerosis: a series of 21 cases. Ann Rheum Dis 2008;67:901903.

4. Lourbopoulos A, Ioannidis P, Boura E, Antoniadis D, Karacostas D, Grigoriadis N. Coexistence of multiple sclerosis and ankylosing spondylitis: report of two cases. Eur Neurol 2013;70:149-154.

5. Omair MA, Alnaqbi KA, Lee P. Rituximab in a patient with ankylosing spondylitis with demyelinating disease: a case report and review of the literature. Clin Rheumatol 2012;31:1259-1261. 